Stanisław Bożyk

Uniwersytet $w$ Bialymstoku

\title{
STATUS USTROJOWY WŁADZY WYKONAWCZEJ W REPUBLICE ARGENTYNY
}

\section{Konstytucyjne podstawy ustroju Argentyny}

Podstawy prawnoustrojowe Republiki Argentyny określa jedna z najstarszych konstytucji latynoamerykańskich, która została przyjęta w dniu 1 maja 1853 r. ${ }^{1}$ Konstytucja ta miała ukształtować trwałe podstawy ustroju politycznego i społecznogospodarczego państwa oraz oprzeć go na istotnie zmodyfikowanych, w stosunku do obowiązujących wcześnie regulacji konstytucyjnych, zasadach ustrojowych. Pod względem przyjętej systematyki, jak też kształtu instytucji ustrojowych, konstytucja z 1853 r. wzorowana była na modelu konstytucyjnym Stanów Zjednoczonych Ameryki, którego założenia legły zresztą także u podstaw regulacji ustanowionych w obu poprzednich argentyńskich konstytucjach ${ }^{2}$. Poza tym korzystała ona z rozwiązań ustrojowych, które wprowadzono wcześniej w konstytucjach niektórych państw Ameryki Łacińskiej (przede wszystkim w konstytucji Republiki Chile z 1833 r.). Konstytucja Republiki Argentyńskiej z 1853 r. okazała się niezwykle trwałym dokumentem ustrojowym, bowiem z późniejszymi zmianami oraz uzupełnieniami obowiązuje już ponad 160 lat.

Nie znaczy to oczywiście, że jej zasady i rozwiązania były konsekwentnie przestrzegane przez te wszystkie lata. Rzeczywistość okazała się bowiem inna, gdyż niestabilność rządów, rządy dyktatorskie, znacząca rola sił zbrojnych oraz ostra walka polityczna prowadziły do tego, że obowiązujące przepisy konstytucyjne były niejednokrotnie naruszane, a nawet dochodziło do zawieszania ich stosowania. W konsekwencji faktycznie funkcjonujący system polityczno-ustrojowy Argentyny,

1 Konstytucję z 1853 r. uchwalił Kongres Konstytucyjny, którego obrady odbywały się w Santa Fe. O pracach tego Kongresu i jego końcowych efektach zob. szerzej m.in. C.R. Lorenzo, Manual de historia constitutional Argentina, T. 2, Rosario 2000 , s. 217 i n.

2 Od proklamowania niepodległości Argentyny w 1816 r., w krótkim okresie czasu uchwalono dwie konstytucje: w 1819 i 1826 r. Oba te akty ustrojowe nie miały w praktyce większego znaczenia, gdyż ich postanowienia nie były z reguły przestrzegane, a zarazem nie obowiązywały na terytorium całego państwa. Por. J.R. Rosas Lopez, Historia constitutional Argentina, Buenos Aires 2014, s. 259 i n. 
podobnie jak innych państw Ameryki Łacińskiej, odbiegał często od ukształtowanych i formalnie obowiązujących zasad konstytucyjnych.

Ostatni reżim wojskowy funkcjonował w Argentynie w latach 1976-1983². Została wtedy uchylona konstytucja, rozwiązano Kongres i parlamenty wszystkich prowincji, przywrócono cenzurę, zakazano działalności partii politycznych oraz zwoływania zgromadzeń 4 . O upadku tego reżimu, stosującego różne formy przemocy i tortury wobec przeciwników politycznych ${ }^{5}$, zadecydowała przede wszystkim porażka wojsk argentyńskich w wojnie o Falklandy. Rozpoczął się wtedy w Argentynie proces odbudowy instytucji i rządów demokratycznych, przywrócono obowiązywanie ustawy zasadniczej, ponownie zaczęto przeprowadzać wolne wybory prezydenckie i parlamentarne ${ }^{6}$. Podjęto też prace nad nową konstytucją, ale w końcu ograniczono się jedynie do kolejnej rewizji obowiązującego aktu konstytucyjnego z 1853 r. Rewizja ta dokonana została przez Zgromadzenie Konstytucyjne w dniu 22 sierpnia 1994 r. 7 , a jej zasadniczym celem było wprowadzenie do ustroju Argentyny takich rozwiązań, które oznaczałyby w pewnym zakresie parlamentaryzację istniejącego w tym państwie systemu rządów prezydenckich.

Konstytucja Argentyny ${ }^{8}$ zawiera podstawowe zasady ustrojowe w rozdziale 1, noszącym tytuł „Zasady, prawa i ich gwarancje”. Normy zawarte w tym rozdziale otwiera przepis art. 1, w którym określono w sposób generalny charakter państwa. Stanowi on, że: „Republika Argentyny przyjmuje przedstawicielską i republikańską formę rządu oraz ustrój federacyjny, w zgodności z tym, co stanowi niniejsza konstytucja”. Ze sformułowania art. 1 wynikają zarazem trzy generalne zasady ustroju politycznego: 1) zasada państwa demokratycznego, 2) zasada rządów przedstawicielskich, 3) zasada federalizmu?.

Zasada państwa demokratycznego wynika z tych sformułowań argentyńskiej ustawy zasadniczej, które sytuują naród w charakterze podmiotu władzy najwyższej w państwie, gwarantują obywatelom szeroki zakres praw i wolności politycznych, deklarują pluralizm ideologiczny i polityczny, kształtują strukturę władz publicznych i relacje między nimi na zasadach demokratycznych, przewidują podejmo-

Wojsko dokonało zamachu stanu w dniu 24 marca 1976 r., występując przeciwko nieudolnym rządom Isabel Martinez de Perón, która przejęła urząd prezydenta Argentyny dwa lata wcześniej po nagłej śmierci swego męża Juana Peróna. W okresie jego prezydentury sprawowała ona urząd wiceprezydenta. 
wanie istotnych dla państwa rozstrzygnięć większością głosów, tworzą podstawy demokratycznych procedur tworzenia prawa. Zasada rządów przedstawicielskich, a więc sprawowanie władzy przez suwerena za pośrednictwem reprezentantów wyłanianych w wyborach powszechnych, była do niedawna w Argentynie jedyną możliwą formą rządów ${ }^{10}$. Zasada federalizmu kształtuje zaś złożoną strukturę państwa, na którą składają się prowincje jako podmioty federacji dysponujące, z mocy obowiązujących przepisów konstytucji, znacznym zakresem samodzielności ${ }^{11}$.

Do podstawowych zasad ustroju Argentyny zalicza się zasadę pluralizmu politycznego (art. 38 konstytucji). Przepis ten stanowi, że ,partie polityczne są podstawowymi instytucjami systemu demokratycznego", deklarując zarazem wolność ich tworzenia oraz podejmowania przez nie wszelkiej działalności, zgodnej jednak z zasadami argentyńskiej konstytucji. Poza tym art. 38 konstytucji gwarantuje organizację i funkcjonowanie partii politycznych zgodnie z zasadami demokracji, w tym zapewnienie właściwej reprezentacji we władzach partyjnych frakcjom mniejszości, przyznaje partiom prawo wysuwania swoich kandydatów w wyborach do różnych organów państwowych oraz wolność głoszenia własnych idei i programów.

Istotną zasadą ustroju politycznego Republiki Argentyny, określającą przy tym wzajemne relacje pomiędzy naczelnymi organami państwa, jest zasada podziału i równowagi władz. Zasada ta nie została sformułowana wprost, tak jak czynią to zwykle inne konstytucje, lecz analiza treści argentyńskiej konstytucji nie pozostawia wątpliwości, że zasada ta kształtuje ustrój naczelnych organów państwowych ${ }^{12}$. Przekonuje o tym także ukształtowana struktura ustawy zasadniczej, gdyż jej trzy rozdziały w części drugiej traktują kolejno: „O władzy ustawodawczej”, „O władzy wykonawczej”, „O władzy sądowniczej”.

Do sprawowania władzy ustawodawczej powołany został parlament, na co jednoznacznie wskazuje art. 44 konstytucji. Stwierdza on, że: „,Władzę ustawodawczą w Republice sprawuje Kongres Narodowy, który składa się z dwóch izb - Izby Deputowanych, reprezentującej Republikę, oraz Senatu, wywodzącego się z prowincji i miasta Buenos Aires". Sferę władzy wykonawczej art. 87 konstytucji powierza Prezydentowi Republiki Argentyny, pełniącemu też klasyczne funkcje głowy państwa. Z kolei władza sądownicza - na mocy art. 108 ustawy zasadniczej - sprawowana jest przez Sąd Najwyższy oraz sądy niższych instancji. Każda z władz federalnych została przy tym wyposażona w takie uprawnienia, które umożliwiają jej oddziaływanie na obie pozostałe władze. Ten system wzajemnych hamulców, wzorowany w znacznym stopniu na zasadach i rozwiązaniach ustrojowych stosowanych w systemie konstytucyjnym Stanów Zjednoczonych, pozwala na zachowanie względnej

\footnotetext{
10 Dopiero podczas rewizji konstytucji w 1994 r. do systemu ustrojowego Argentyny wprowadzone zostały trzy instytucje demokracji bezpośredniej: inicjatywa ludowa, referendum ustawodawcze i powszechne konsultacje obywatelskie, które przybierają postać referendum konsultacyjnego. racji posiada własną konstytucję oraz prowincjonalne organy władzy ustawodawczej i wykonawczej. 
równowagi między władzą ustawodawczą, wykonawczą i sądowniczą ${ }^{13}$, co zalicza się zawsze do jednej z najbardziej charakterystycznych cech modelu rządów prezydenckich.

\section{System rządów}

W systemie ustrojowym Argentyny poszczególne władze, tak jak w systemie ustrojowym Stanów Zjednoczonych i w ustrojach politycznych innych państw latynoamerykańskich, są od siebie niezależne. Ta niezależność przejawia się faktycznie w trzech zasadniczych sferach: funkcjonalnej, organizacyjnej oraz personalnej. Widoczna jest ona przede wszystkim w aspekcie organizacyjnym i personalnym, gdzie ma miejsce daleko idąca separacja władz. Niezależność oraz separacja poszczególnych władz nie są już jednak tak oczywiste $\mathrm{w}$ ich aspekcie funkcjonalnym. Tutaj możemy mówić raczej o wzajemnym, mniej lub bardziej dostrzegalnym, podziale kompetencji. Tym bardziej, że niektóre kompetencje przenikają się pomiędzy władzą ustawodawczą, wykonawczą i sądowniczą.

Podejmując próbę charakterystyki każdego współczesnego systemu rządów należy mieć na uwadze, że decydujące znaczenie ma w tym wypadku określenie wzajemnych relacji między parlamentem a egzekutywą. W Republice Argentyny relacje te oparte zostały na zasadach właściwych dla klasycznego modelu rządów prezydenckich. System rządów w tym państwie cechowała od początku daleko idąca separacja władz, w ramach której wyeksponowana była zazwyczaj pozycja prezydenta jako szefa administracji federalnej. Taka pozycja urzędującej głowy państwa stanowiła zresztą, i do tej pory stanowi, konsekwencję ukształtowania w tym systemie ustrojowym jednoczłonowej egzekutywy ${ }^{14}$.

Wspomniana separacja władz w systemie konstytucyjnym Argentyny nie jest jednak pełna, gdyż część kompetencji poszczególnych władz federalnych przenika między sobą ${ }^{15}$. Władza ustawodawcza (parlament) ma zapewnione pewne środki oddziaływania na funkcjonowanie egzekutywy (prezydenta), ale też prezydent został uprawniony do podejmowania określonych działań wobec parlamentu, chociażby poprzez wykorzystywanie inicjatywy ustawodawczej. Organy władzy sądowniczej także dysponują konstytucyjnymi uprawnieniami, które dają im możliwość zaznaczania widocznej roli w relacjach z władzą ustawodawczą i wykonawczą. W pierwszej kolejności należałoby tu wymienić prawo Sądu Najwyższego do kontroli zgodności z konstytucją ustaw Kongresu Narodowego oraz aktów normatywnych podejmowanych przez prezydenta Republiki.

13 O wzajemnych relacjach między parlamentem, prezydentem oraz władzą sądowniczą zob. G.N. Molinelli, V.M. Palanza, G. Sin, Congreso, presidencia y justicia en Argentina, Buenos Aires 1999, s. 16 i n.

14 Por. M.A. Ekmekdjian, Tratado de derecho constitucional. Constitución de la Nación Argentina, comentada, y anotada con legislacion, jurisprudencia y doctrina, T. 5, Buenos Aires 2004, s. 26 i n. 
Parlamentowi (Kongresowi Narodowemu) wyznaczona została tradycyjna rola władzy ustawodawczej, zajmującej się przede wszystkim tworzeniem ustaw. Poza wykonywaniem kompetencji w ramach tej funkcji, argentyński parlament realizuje też drugą klasyczną funkcję każdego parlamentu, a mianowicie funkcję kontrolną. W systemie prezydenckim Argentyny ta sfera aktywności Kongresu Narodowego nie jest jednak wiodąca, bowiem parlament ma bardzo ograniczone możliwości realizacji uprawnień kontrolnych wobec organów egzekutywy ${ }^{16}$.

Analizując stosunki pomiędzy Kongresem Narodowym a prezydentem Republiki można zauważyć, że stosunki te uległy pewnej zmianie po rewizji konstytucji Argentyny w 1994 r. Wcześniej prezydent zajmował niejednokrotnie nadrzędną pozycję nad innymi organami państwa, w tym także nad parlamentem ${ }^{17}$. Obecnie relacje między władzą ustawodawczą a sprawującym funkcje głowy państwa prezydentem ukształtowane są na zasadzie względnej równowagi. Prezydent podpisuje ustawy uchwalone przez parlament i może korzystać z prawa weta zawieszającego, do niego też należy otwieranie sesji parlamentu. Prezydent nie ponosi jednak odpowiedzialności politycznej przed parlamentem.

W stosunku do urzędującego prezydenta konstytucja Argentyny gwarantuje parlamentowi przede wszystkim znaczący udział w procedurze egzekwowania odpowiedzialności prawnej prezydenta Republiki. Zgodnie z art. 53 konstytucji, w sytuacji, kiedy prezydent naruszy przepisy prawa lub popełni przestępstwo, Izba Deputowanych może postawić go w stan oskarżenia przed Senatem. Gdyby Senat zadecydował o winie prezydenta, oznaczałoby to bezzwłoczne odwołanie prezydenta z zajmowanego urzędu. W systemie konstytucyjnym Republiki Argentyny szczególna rola w procedurze wygaszenia kadencji urzędującej głowy państwa wyznaczona więc została, tak jak ma to miejsce wszędzie tam, gdzie praktykowana jest klasyczna konstrukcja impeachment, organowi władzy ustawodawczej ${ }^{18}$.

Egzekutywa w Argentynie jest jednoczłonowa, bowiem prezydent jest jednocześnie głową państwa oraz szefem administracji federalnej. Jego pozycję ustrojową, także w stosunku do federalnego parlamentu, wzmacnia istotnie fakt obsady tego urzędu w drodze powszechnych i bezpośrednich wyborów prezydenckich. Decydują o tym także bardzo szerokie uprawnienia prezydenta, które gwarantuje mu obowiązująca konstytucja. Znaczącego statusu ustrojowego prezydenta Argentyny nie osłabiło bynajmniej utworzenie w 1994 r. urzędu Szefa Gabinetu Ministrów ${ }^{19}$. Ten urzędnik federalny powoływany jest przez prezydenta i tylko jemu podlega. Wielce interesującą nowością jest jednak niewątpliwie to, że konstytucja wprowadziła zasadę odpowiedzialności politycznej Szefa Gabinetu Ministrów przed Kon-

\footnotetext{
16 Istotnie ograniczone możliwości realizacji przez parlament klasycznej funkcji kontrolnej to jedna z najbardziej specyficznych cech każdego prezydenckiego systemu rządów.

17 Sytuacja taka miała miejsce szczególnie wtedy, gdy prezydent nie był wyłaniany w wyborach, lecz sprawował ten urząd wskutek zamachu stanu czy przewrotu wojskowego.

18 Por. M.A. Ekmekdjian, Tratado de derecho..., op. cit., T. 4, s. 306 i n.

19 Por. J.V. Sola, Manual de derecho constitucional, Buenos Aires 2010, s. 244 i n.
} 
gresem Narodowym. Takie zmiany w ustroju państwa nie spowodowały, co prawda, odejścia Argentyny od systemu prezydenckiego, ale stały się przejawem parlamentaryzacji tego systemu rządów.

Prezentując system rządów w Argentynie nie można pominąć wzajemnych relacji, jakie zachodzą pomiędzy Kongresem Narodowym i prezydentem a władzą sądowniczą. Najwyższą instancją sądową w Argentynie jest Sąd Najwyższy, którego sędziowie powoływani są przez prezydenta Republiki. Sąd Najwyższy jest jednak niezawisły i niezależny od pozostałych władz, stąd też Kongres Narodowy (poza stanowieniem ustaw kształtujących ustrój sądów) nie posiada żadnych konstytucyjnych i ustawowych podstaw do oddziaływania na naczelny organ władzy sądowniczej.

\section{Wybory prezydenckie}

Konstytucja Argentyny z 1853 r. w jej pierwotnym brzmieniu przewidywała dokonywanie wyboru prezydenta w wyborach pośrednich, poprzez kolegium elektorskie, a więc na wzór trybu wyboru prezydenta Stanów Zjednoczonych. Taka też procedura obsady urzędu głowy państwa stosowana była w praktyce, z wyjątkiem bardzo krótkiego epizodu podczas pierwszej prezydentury Juana Peróna ${ }^{20}$. Po rewizji ustawy zasadniczej w 1994 r. przyjęto w Argentynie zasadę powszechnych i bezpośrednich wyborów prezydenckich. Deklaruje ją jednoznacznie przepis art. 94 konstytucji, stwierdzający, że: „Prezydent i wiceprezydent są wybierani w wyborach bezpośrednich, przeprowadzanych $\mathrm{w}$ dwóch turach i zgodnie z postanowieniami niniejszej konstytucji”.

Podstawowe zasady prawa wyborczego w Republice Argentyny sformułowane zostały w ustawie zasadniczej. Przepis art. 37 konstytucji wprowadza w tym zakresie klasyczne zasady prawa wyborczego: powszechności, równości oraz tajności głosowania, a ponadto przyjmuje zasadę obowiązkowego głosowania. Zasadnicze rozstrzygnięcia odnoszące się już tylko do wyborów na urząd prezydenta znalazły się natomiast w tej części konstytucji, która nosi tytuł „O trybie i terminach przeprowadzenia wyborów prezydenta i wiceprezydenta" ${ }^{21}$.

W wyborach prezydenckich czynne prawo wyborcze, analogicznie jak podczas wyborów do obu izb Kongresu Narodowego, przyznane zostało osobom posiadającym argentyńskie obywatelstwo od urodzenia bądź też nabyte w wyniku naturalizacji. Do niedawna prawo głosowania przysługiwało tym obywatelom Argentyny,

20 Po nowelizacji konstytucji w 1949 r. wprowadzono do niej zasadę powszechnych i bezpośrednich wyborów na urząd prezydenta Argentyny. Ta procedura wyborów prezydenckich była wówczas zastosowana tylko raz - w takim trybie 11 listopada 1951 r. na urząd prezydenta wybrany został Juan Peron. Warto przy tym wspomnieć, że podczas tych wyborów pierwszy raz w historii Argentyny mogły głosować kobiety, którym nieco wcześniej przyznano powszechne prawo wyborcze (o co walczyła ówczesna żona prezydenta - Evita Perón). Po obaleniu Peróna w wyniku przewrotu wojskowego w 1955 r., powrócono jednak do pośrednich wyborów prezydenckich.

21 Szczegółowa regulacja trybu organizacji oraz przeprowadzania wyborów znajduje się w kodeksie wyborczym z 1983 r. Zob. Codigo Electoral National, Ley № 19.945, Boletin Oficial del 18.08.1983. 
którzy najpóźniej w dniu głosowania mieli ukończonych 18 lat. W wyniku ostatniej nowelizacji przepisów argentyńskiego kodeksu wyborczego w 2012 r., czynne prawo wyborcze przyznano także osobom w wieku od 16 do 18 lat, przy czym ci najmłodsi wyborcy, w przeciwieństwie do obywateli po 18. roku życia, nie mają prawnego obowiązku udziału w głosowaniu ${ }^{22}$. Czynnego prawa wyborczego nie posiadają zaś osoby ubezwłasnowolnione orzeczeniem sądu z powodu choroby psychicznej, skazani prawomocnym wyrokiem sądu za naruszenia prawa wymienione $\mathrm{w}$ art. 3 kodeksu wyborczego, osoby odbywające karę pozbawienia wolności oraz osoby pozbawione prawa wyborczego na podstawie ustawy organicznej o partiach politycznych.

Przy prezentacji ram czynnego prawa wyborczego, należy także pamiętać o konstytucyjnej zasadzie obowiązkowego udziału obywateli w wyborach. Argentyna wprowadziła tę formułę już w 1912 r., a więc była jednym z pierwszym państw w świecie, które zastosowały przymus wyborczy ${ }^{23}$. Obecnie obowiązek głosowania nakłada przepis art. 12 kodeksu wyborczego ${ }^{24}$, który wylicza zarazem osoby, których ten obowiązek nie obejmuje. Zalicza do nich: 1) osoby, które ukończyły 70 lat, 2) osoby między 16. a 18. rokiem życia, 3) sędziów i ich pomocników, którzy w dniu wyborów muszą być w pracy, gwarantując w ten sposób dostęp wyborców do sądu, 4) osoby przebywające w dniu wyborów w odległości ponad $500 \mathrm{~km}$ od stałego miejsca zamieszkania, 5) chorych i inwalidów, 6) pracowników organów i służb publicznych.

Bierne prawo wyborcze w wyborach prezydenckich określa art. 89 konstytucji. Wynika z niego, że prezydentem może być tylko obywatel urodzony na terytorium Republiki Argentyny lub urodzony za granicą, ale pod warunkiem, że jeden $\mathrm{z}$ jego rodziców posiadał argentyńskie obywatelstwo od urodzenia. Poza tym kandydat na prezydenta Argentyny, analogicznie jak kandydaci na senatorów, musi mieć ukończonych 30 lat oraz być obywatelem Republiki przez co najmniej sześć lat przed wyborami. Z kolei przepis art. 90 ustawy zasadniczej reguluje kwestie kadencji prezydenta i wiceprezydenta, stanowiąc, że wynosi ona 4 lata. Warto jednak zaznaczyć, że w systemie konstytucyjnym Argentyny przewidywana jest możliwość nawet wielokrotnej reelekcji prezydenta, ale nieprzerwanie prezydent może sprawować swój urząd jedynie przez dwie kolejne kadencje ${ }^{25}$.

W obowiązującym obecnie stanie prawnym, kandydaci na urząd prezydenta Argentyny są wyłaniani $\mathrm{w}$ drodze prawyborów ${ }^{26}$. Zasadniczym celem tego etapu

Zob. szerzej J.M. Pérez Corti, Derecho electoral Argentino, Córdoba 2012, s. 52 i n.

Por. G. Badeni, Tratado de derecho..., op. cit., T. 1, s. 998 i n.

W przypadku nieusprawiedliwionej absencji podczas głosowania przewidywana jest kara grzywny. W trakcie ostatnich wyborów parlamentarnych wynosiła ona minimum 50 pesos.

25 Przykładowo, sprawująca w latach 2007-2015 urząd prezydenta Argentyny Cristina Fernandez de Kirchner mogłaby ponownie kandydować w wyborach prezydenckich dopiero w 2019 roku.

26 Instytucja prawyborów wprowadzona została do systemu wyborczego Argentyny stosunkowo niedawno, bo w drodze ustawy z dnia 2 grudnia 2009 r. Ley № 26.571: Ley de democratización de la representación politica, la transparencia y la equidad electoral, Boletin Oficial del 2.12.2009. 
postępowania wyborczego jest wyłonienie kandydatów, którzy mają następnie uczestniczyć we właściwym głosowaniu. Kandydaci na urząd prezydenta i wiceprezydenta Republiki Argentyny muszą otrzymać podczas prawyborów co najmniej 1,5\% głosów w skali całego kraju ${ }^{27}$.

Zarówno podczas prawyborów, jak i w trakcie właściwego głosowania, terytorium całego kraju, zgodnie z postanowieniem art. 94 konstytucji, stanowi jeden okręg wyborczy. W art. 95 konstytucji przewiduje się z kolei, że wybory prezydenckie muszą być przeprowadzone w okresie dwóch miesięcy, które poprzedzają upływ kadencji urzędującego prezydenta.

Konstytucja Argentyny przewiduje zasadniczo przeprowadzanie wyborów prezydenckich w dwóch turach. W tej kwestii art. 96 stanowi, że w drugiej turze, gdy prezydent nie zostanie wyłoniony w pierwszej turze głosowania, wyborcy głosują na jedną z dwóch ,połączonych kandydatur”, czyli tzw. formułę ${ }^{28}$. Tworzą ją dwie pary kandydatów (na urząd prezydenta i wiceprezydenta), które zebrały najwięcej głosów podczas pierwszej tury głosowania. Druga tura musi być przeprowadzona w ciągu 30 dni od zakończenia pierwszego głosowania. Wybory wygrywają wówczas ci kandydaci, którzy w drugiej turze uzyskają większość ważnie oddanych głosów.

Przepis art. 97 przewiduje jednak, że jeśli kandydaci na prezydenta i wiceprezydenta, zebrawszy w sumie najwięcej głosów, zdobędą w pierwszej turze ponad 45\% głosów, zostają ogłoszeni prezydentem i wiceprezydentem Republiki Argentyny. Jeszcze inną możliwość rozstrzygnięcia wyniku wyborów prezydenckich już w pierwszej turze przewiduje art. 98 konstytucji. Stanowi on, że jeśli na jednego z kandydatów na urząd prezydenta (oraz na kandydata na urząd wiceprezydenta) w trakcie pierwszej tury głosowania zostało oddanych ponad $40 \%$ głosów, a przewaga nad następnymi w kolejności kandydatami wynosi ponad 10\%, to również nie przewiduje się przeprowadzania drugiej tury wyborów ${ }^{29}$.

Należy jeszcze dodać, że w wyborach prezydenckich w Argentynie liczą się każdorazowo kandydaci jedynie dwóch najsilniejszych partii politycznych, które od ponad trzydziestu lat wyraźnie dominują w systemie partyjnym tego państwa. Pierwszą z nich jest Obywatelska Unia Radykalna (Unión Civica Radical, UCR) ${ }^{30}$, drugą zaś Partia Sprawiedliwości (Partido Justicialista, PJ) ${ }^{31}$. Od 1983 r. wybory prezydenc-

27 Pierwsze w Argentynie prawybory parlamentarne oraz prezydenckie przeprowadzono 14 sierpnia 2011 roku. Znalazły one zastosowanie także w kolejnych wyborach, stając się zapewne trwałą instytucją ustrojową w tym państwie.

28 W oryginale fórmula de candidatos. 29 Dwie poprzednie elekcje na urząd prezydenta Argentyny rozstrzygnięte zostały w pierwszej turze głosowania. na jej kandydaturę także w pierwszej turze oddano $54,1 \%$ głosów.

30 UCR istnieje od 1891 r. i jest najstarszą ze wszystkich funkcjonujących dzisiaj partii politycznych Argentyny. Partia ta w swoim programie łączy elementy radykalizmu oraz liberalizmu.

31 PJ została założona przez Juana Peróna w 1945 r. i jest zaliczana do nurtu socjaldemokratycznego. W sferze programowej PJ różni się od UCR przede wszystkim tym, że opowiada się za szerokim zakresem świadczeń so- 
kie wygrywali częściej politycy PJ, którzy kilkakrotnie pełnili w tym okresie urząd prezydenta Argentyny: Carlos Menem (1989-1999), Néstor Kirchner (2003-2007) oraz Cristina Fernández de Kirchner (2007-2015) ${ }^{32}$.

\section{Status ustrojowy i kompetencje Prezydenta Republiki}

Konstytucja Republiki Argentyny z 1853 r. ukształtowała status ustrojowy prezydenta nader ogólnie, gwarantując mu jednak zarazem bardzo silną pozycję w strukturze federalnych organów państwa. Od początku prezydent miał być jedynym organem władzy wykonawczej na szczeblu federacji, pełniąc zwłaszcza funkcje głowy państwa w stosunkach wewnętrznych i międzynarodowych. W kwestii obsady urzędu prezydenta przyjęto wówczas, że funkcja ta będzie obsadzana w sposób pośredni, a więc przez kolegium elektorskie wyłaniane przez obywateli w drodze wyborów powszechnych.

Także obecnie argentyńska konstytucja zawiera stosunkowo skromną regulację statusu ustrojowego prezydenta ${ }^{33}$. Niemniej jednak po rewizji konstytucji z $1994 \mathrm{r}$. polityczna rola głowy państwa i szefa administracji federalnej uległa wzmocnieniu poprzez przyjęcie zasady powszechnych i bezpośrednich wyborów prezydenckich. Fakt wyboru prezydenta przez ogół obywateli wzmocnił bowiem niewątpliwie polityczną legitymizację tego urzędu w systemie konstytucyjnym współczesnej Argentyny ${ }^{34}$.

Przepis art. 90 konstytucji stanowi, że okres sprawowania funkcji przez prezydenta oraz wiceprezydenta wynosi 4 lata. Tak zarysowana kadencja prezydenta rozpoczyna się w dniu formalnego objęcia przez niego urzędu i trwa każdorazowo do chwili, kiedy następuje upływ jego czteroletnich pełnomocnictw ${ }^{35}$. Przy obejmowaniu urzędu prezydent składa przysięgę, której tekst zawiera art. 93 konstytucji. Wówczas prezydent przysięga ,wiernie i z oddaniem realizować kompetencje prezydenta, sumiennie przestrzegać oraz zapewniać przestrzeganie Konstytucji Argentyny”. Zaprzysiężenie nowo wybranego prezydenta odbywa się zawsze na wspólnym posiedzeniu obu izb federalnego parlamentu, które tworzą wówczas Zgromadzenie Narodowe.

Przewidziana w art. 90 konstytucji Argentyny czteroletnia kadencja prezydenta może ulec skróceniu. Urząd prezydenta może być bowiem opróżniony w przypadku

cjalnych dla najuboższych, wspiera związki zawodowe oraz dąży do współpracy z krajami członkowskimi BRICS (Brazylia, Rosja, Indie, Chiny, RPA).

32 Poczynając od 1991 r., po przeprowadzanych co 2 lata wyborach częściowych do Izby Deputowanych, PJ posiada też stale największą liczbę mandatów w tej izbie parlamentu federalnego Argentyny.

33 Prezydentowi poświęcony został fragment ustawy zasadniczej noszący tytuł „O władzy wykonawczej”, gdzie uregulowano też status Szefa Gabinetu Ministrów i ministrów. Bezpośrednio do prezydenta odnosi się w tej części konstytucji zaledwie 14 artykułów. W dodatku większość z nich traktuje o zasadach i trybie dokonywania wyborów prezydenckich.

34 Zob. szerzej M.A. Ekmekdjian, Tratado de derecho..., op. cit., T. 5, s. 23 i n.

35 Por. A.R. Dalla Via, Manual de derecho..., op. cit., s. 449 i n. 
śmierci prezydenta, niemożności dalszego pełnienia przez niego funkcji z powodu poważnej choroby, rezygnacji z tej funkcji bądź też złożenia go z urzędu przez parlament $\mathrm{w}$ wyniku zastosowania procedury impeachment. W tych przypadkach, zgodnie $\mathrm{z}$ art. 88 ustawy zasadniczej, funkcje prezydenta przejmuje urzędujący wiceprezydent, który sprawuje wówczas urząd głowy państwa i szefa administracji federalnej, tak jak ma to stale miejsce w Stanach Zjednoczonych, do upływu konstytucyjnej kadencji dotychczasowego prezydenta, czyli do czasu wyłonienia nowego prezydenta w drodze powszechnych i bezpośrednich wyborów prezydenckich.

Przepis art. 88 przewiduje również taką sytuację, kiedy z wyżej wymienionych powodów nastąpi jednoczesne opróżnienie obu urzędów, czyli prezydenta i wiceprezydenta. W takich okolicznościach Kongres Narodowy zobowiązany jest do powołania osoby, która pełniłaby tymczasowo funkcje prezydenta Republiki. Sprawa czasowego zastępstwa prezydenta została uregulowana w ustawie o wykonywaniu obowiązków prezydenta i wiceprezydenta, przyjętej przez argentyński parlament w $1975 \mathrm{r} .{ }^{36}$ Ustawa ta $\mathrm{w}$ art. 1 stanowi, że przy jednoczesnym opróżnieniu urzędów prezydenta i wiceprezydenta, funkcje władzy wykonawczej mogą być sprawowane kolejno przez: 1) przewodniczącego Senatu pro tempore, czyli osobę pełniącą obowiązki przewodniczącego drugiej izby parlamentu wtedy, gdy wiceprezydent z ważnego powodu nie może czasowo kierować pracami Senatu ${ }^{37}, 2$ ) stałego przewodniczącego Izby Deputowanych, 3) prezesa Sądu Najwyższego. Osoba powołana do pełnienia tych funkcji może je realizować, zgodnie z przepisami ustawy z 1975 r., jedynie do momentu wyboru nowego prezydenta i wiceprezydenta.

Konstytucyjny zakres uprawnień prezydenta Republiki Argentyny określa enumeratywnie art. 99 ustawy zasadniczej. Wymienione w tym przepisie uprawnienia prezydenta (w sumie 20 punktów) obejmują różne sfery aktywności głowy państwa. Nie znaczy to oczywiście, że w art. 99 konstytucji wyliczone zostały wszystkie uprawnienia, które mogą być realizowane przez prezydenta. Część jego kompetencji wynika też z innych przepisów konstytucyjnych albo została określona w ustawodawstwie zwykłym ${ }^{38}$.

Ramy konstytucyjne uprawnień prezydenta Argentyny stara się zarysować art. 99 pkt 1, który stanowi, że prezydent Republiki jest „głową państwa i szefem administracji oraz ponosi odpowiedzialność polityczną za ogólny stan zarządzania państwem". Jest to jednak przepis zbyt ogólny, aby na jego podstawie było możliwe wyznaczenie granic kompetencji głowy państwa. W dodatku niejasna jest formuła o odpowiedzialności politycznej prezydenta, gdyż de facto taka odpowiedzialność nie jest możliwa w prezydenckim systemie rządów. Tutaj w grę może wcho-

36 Ley № 20.972: Ley de acefalia del poder ejecutivo, Boletin Oficial del 22.07.1975.

37 Przewodniczący pro tempore wybierany jest zwykle na pierwszym w nowej sesji posiedzeniu Senatu spośród najbardziej doświadczonych senatorów.

38 Por. G. Badeni, Tratado de derecho..., op. cit., T. 2, s. 1705 i n. 
dzić tylko odpowiedzialność konstytucyjna prezydenta w trybie impeachment przed Kongresem Narodowym.

Przepis art. 99 unormował w pierwszej kolejności uprawnienia prawodawcze prezydenta. Przewiduje on w tej materii, że prezydent wydaje instrukcje i regulaminy, które są niezbędne w celu wykonania ustaw federalnych, przy czym zawarte w tych aktach prezydenta normy prawne nie mogą być sprzeczne z duchem uchwalonych wcześniej ustaw. Jednocześnie przepis ten wyraźnie podkreśla, że władzy wykonawczej nie przysługuje uprawnienie do wydawania aktów normatywnych z mocą ustawy. Zarazem jednak przewiduje wyjątek od tej zasady, stanowiąc, że jeśli w szczególnej sytuacji nie będzie możliwe uchwalanie ustaw w zwykłym trybie, przewidzianym w treści konstytucji, prezydent może wydawać dekrety z mocą ustawy. Dekrety te nie mogą regulować niektórych kwestii (np. spraw dotyczących prawa wyborczego i statusu partii politycznych), a poza tym muszą być kontrasygnowane przez ministra lub Szefa Gabinetu Ministrów. Ponadto każdy dekret z mocą ustawy podlega jak najszybszemu rozpatrzeniu i zatwierdzeniu przez obie izby parlamentu ${ }^{39}$.

Postanowienia argentyńskiej konstytucji umożliwiają także prezydentowi aktywny udział $\mathrm{w}$ procedurze ustawodawczej $\mathrm{i}$ to $\mathrm{w}$ dwóch stadiach tego postępowania. Prezydent posiada prawo inicjatywy ustawodawczej i tym samym może wnosić projekty ustaw do rozpatrzenia przez izby Kongresu Narodowego ${ }^{40}$. W tej materii głowa państwa jest też niekiedy jedynym podmiotem posiadającym prawo zgłoszenia projektu aktu ustawodawczego. Odnosi się to przede wszystkim do projektu ustawy budżetowej, gdzie wyłączna inicjatywa ustawodawcza przysługuje prezydentowi Republiki. Do kompetencji prezydenta należy ponadto promulgacja każdej ustawy uchwalonej przez parlament, co jest niezbędne w celu ogłoszenia i wejścia w życie ustawy ${ }^{41}$. Prezydent może przy tym odmówić podpisania ustawy, czyli skorzystać z przysługującego mu prawa weta zawieszającego ${ }^{42}$.

Poza udziałem w procesie tworzenia przez parlament aktów ustawodawczych, prezydent Argentyny nie ma już bardziej znaczących uprawnień w stosunku do parlamentu federalnego. Do niego należy jednak otwieranie corocznych sesji parlamentu, który w tym celu zbiera się na wspólne posiedzenie Izby Deputowanych i Senatu. Prezydentowi przysługują wówczas inne konstytucyjne uprawnienia, a mianowicie przedstawia on na tym posiedzeniu Kongresu orędzie o stanie państwa, ale może też proponować podjęcie przez parlament określonych reform czy wprowadzenie zmian

39 Po instytucję dekretu z mocą ustawy sięgał często przede wszystkim prezydent Carlos Menem, sprawujący swój urząd w latach 1989-1999. Dekrety te były jednak najczęściej zatwierdzane przez Kongres Narodowy.

40 Por. E. Menem, Derecho procesal parlamentario, Buenos Aires 2012, s. 218 i n.

41 Por. np. S. Bożyk, Konstytucyjny status parlamentu w państwach Ameryki Łacińskiej (Argentyna, Kolumbia, Meksyk), (w:) M. Grzybowski, G. Kuca, P. Mikuli (red.), Ustroje. Historia i współczesność. Polska - Europa - Ameryka Łacińska, Kraków 2013, s. 347. 42 Parlament ma możliwość odrzucenia weta prezydenta, ale wymaga to kwalifikowanej większości $2 / 3$ głosów 
ustawodawczych. Do kompetencji prezydenta wobec władzy ustawodawczej należy ponadto przedłużanie sesji zwyczajnych parlamentu oraz zwoływanie, w miarę zaistnienia takich konieczności, sesji nadzwyczajnych.

Jako osobną grupę uprawnień prezydenta należy traktować przysługujące mu kompetencje jako szefa administracji federalnej. Przede wszystkim posiada on uprawnienia $\mathrm{w}$ zakresie obsady wielu stanowisk w tej administracji, w tym powoływanie ministrów, sekretarzy stanu i wreszcie Szefa Gabinetu Ministrów. Prezydent sprawuje jednocześnie kontrolę działalności urzędników federalnych i tym samym może żądać przedstawiania przez nich wszelkiego rodzaju sprawozdań oraz informacji. Szef Gabinetu Ministrów oraz inni urzędnicy federalni podlegają bezpośrednio prezydentowi i mogą być przez niego odwoływani.

Prezydentowi Argentyny przysługują tradycyjne uprawnienia wobec władzy sądowniczej. Należy do nich przede wszystkim prawo powoływania sędziów Sądu Najwyższego, z tym że może być ono realizowane wyłącznie za zgodą Senatu. Prezydent mianuje również sędziów sądów federalnych niższego szczebla. Także w tym wypadku wymaga się wyrażenia zgody przez Senat na dokonywane przez niego nominacje. W tej grupie kompetencji prezydenta mieści się też oczywiście stosowanie prawa łaski.

Argentyńska ustawa zasadnicza przyznaje prezydentowi funkcje naczelnego dowódcy sił zbrojnych Republiki ${ }^{33}$. W tym zakresie posiada on przede wszystkim prawo dysponowania siłami zbrojnymi w celu zapewnienia porządku wewnętrznego oraz obrony państwa na wypadek obcej interwencji wojskowej. Prezydentowi przysługują jednocześnie uprawnienia do obsady różnych stanowisk wojskowych oraz mianowania na stopnie oficerskie.

$\mathrm{Z}$ tą sferą uprawnień prezydenta wiążą się jego uprawnienia nadzwyczajne, które dotyczą $\mathrm{w}$ głównej mierze spraw z zakresu bezpieczeństwa i obronności państwa. W art. 99 konstytucji przyznano prezydentowi prawo wypowiedzenia wojny oraz wprowadzenia stanu oblężenia (estado de sitio), ale tylko w sytuacji zewnętrznego zagrożenia państwa lub dokonania obcej agresji na terytorium Argentyny ${ }^{44}$. Stan oblężenia może być zarządzony przez prezydenta Republiki także w przypadku pojawienia się zagrożeń o charakterze wewnętrznym, jednak tylko podczas przerwy w pracach parlamentu federalnego ${ }^{45}$.

Do zadań prezydenta Argentyny należy ponadto wykonywanie określonych kompetencji głowy państwa w dziedzinie stosunków międzynarodowych. W tym zakresie prezydent Republiki: reprezentuje państwo w stosunkach międzynarodowych ${ }^{46}$, zawiera oraz podpisuje umowy międzynarodowe $\mathrm{z}$ innymi państwami

Zob. szerzej G. Badeni, Tratado de derecho..., op. cit., T. 2, s. 1736 i n.

Por. H. J. Zarini, Constitución Argentina. Comentada y concordada, Buenos Aires 2013, s. 489 i n.

W art. 75 konstytucji przewiduje się bowiem, że w przypadku wewnętrznego zagrożenia bezpieczeństwa państwa stan oblężenia wprowadzany jest przez Kongres Narodowy.

Konstytucja Argentyny przewiduje, że prezydent może opuszczać terytorium państwa wyłącznie za zgodą Kongresu Narodowego. 
i organizacjami międzynarodowymi, mianuje przedstawicieli dyplomatycznych Argentyny w innych państwach oraz przy organizacjach międzynarodowych ${ }^{47}$, przyj- $^{-}$ muje listy uwierzytelniające oraz odwołujące przedstawicieli dyplomatycznych innych państw i organizacji międzynarodowych.

\section{Szef Gabinetu Ministrów}

W systemie konstytucyjnym Argentyny struktura władzy wykonawczej jest formalnie jednoczłonowa, bowiem uosabia ją jedynie prezydent Republiki. Od 1994 r. znowelizowana wówczas konstytucja przewiduje już jednak także inne organy administracji federalnej, w tym ministrów powoływanych przez prezydenta ${ }^{48}$. Do ustroju Argentyny wprowadzony też został urząd Szefa Gabinetu Ministrów (El Jefe de Gabinete de Ministros), nie mający w zasadzie swojego odpowiednika w innych państwach Ameryki Łacińskiej ${ }^{49}$. Nie można go również porównywać z europejskimi premierami, gdyż ci stoją na czele sformalizowanych rządów oraz funkcjonują w ramach zupełnie innych modeli ustrojowych. Niemniej jednak sam fakt utworzenia takiego urzędu w Argentynie pozwala stwierdzić, że uczyniono tam pierwszy krok w kierunku parlamentaryzacji prezydenckiego systemu rządów ${ }^{50}$.

Konstytucja Argentyny poświęca Szefowi Gabinetu Ministrów kilka artykułów w części normującej ustrój władzy wykonawczej. Przepis art. 99 stanowi, że Szefa Gabinetu Ministrów powołuje prezydent Republiki, a do tego powołania nie jest wymagana akceptacja Senatu. Z kolei w art. 100 jest mowa o tym, że Szef Gabinetu Ministrów wraz z ministrami sprawuje administrowanie sprawami Republiki. W tym samym przepisie przewidziane jest znaczące uprawnienie Szefa Gabinetu Ministrów, jakim jest niewątpliwie kontrasygnata wszystkich aktów normatywnych podejmowanych przez prezydenta, bez czego akty te nie mogłyby w żaden sposób nabrać mocy obowiązującej.

Przepis art. 100 argentyńskiej konstytucji wylicza enumeratywnie 13 obowiązków Szefa Gabinetu Ministrów ${ }^{51}$. Zaliczono do nich m.in. sprawowanie ogólnej pieczy nad organami administracji federalnej, wydawanie aktów wykonawczych do aktów prawnych prezydenta, wykonywanie zadań delegowanych mu przez prezydenta, mianowanie różnych urzędników administracji (z wyjątkiem tych, których powołuje prezydent), kierowanie projektów ustaw budżetowych do parlamentu,

47 W Argentynie prezydenckie nominacje ambasadorów w innych państwach wymagają zawsze zgody Senatu.

$48 \quad$ Ministrowie (oraz podległe im sekretariaty stanu) realizują w imieniu głowy państwa i tylko z jego inicjatywy wyraźnie określone zadania z zakresu administracji państwowej. O tym ilu ministrów zostanie powołanych, jak też komu powierzone zostaną te funkcje, decyduje każdorazowo prezydent. On też może w każdej chwili usunąć ministra, gdy uzna to za uzasadnione. Por. J.V. Sola, Manual de derecho..., op. cit., s. 239 i n. Jedyny wyjątek stanowi Peru, gdzie utworzony został urząd premiera do nadzorowania pracy poszczególnych ministrów. Niemniej jednak w Peru, tak jak w Argentynie, funkcjonuje prezydencki system rządów.

50 Por. A.R. Dalla Via, Manual de derecho..., op. cit., s. 466 i n.

51 Pozycji ustrojowej oraz obowiązkom Szefa Gabinetu Ministrów poświęcone zostało opracowanie J.I. Barrazy, F.H. Schafrik, El Jefe de Gabinete de Ministros, Buenos Aires 1999, passim. 
udzielanie odpowiedzi na interpelacje kierowane do niego przez deputowanych i senatorów, uczestniczenie przynajmniej raz w miesiącu w posiedzeniach Izby Deputowanych i Senatu. W art. 100 znalazło się też stwierdzenie, że za realizację tych zadań Szef Gabinetu Ministrów ponosi odpowiedzialność polityczną przed Kongresem Narodowym.

Wprowadzenie zasady odpowiedzialności politycznej jednego z urzędników administracji federalnej przed parlamentem to istotna nowość w systemie konstytucyjnym Argentyny. Do tej pory ta postać odpowiedzialności egzekutywy przed legislatywą nie była w zasadzie znana w modelu ustrojowym tego państwa. Przewiduje ją art. 101 konstytucji, dopuszczając przy tym nawet uchwalenie Szefowi Gabinetu Ministrów wotum nieufności. Z przepisu art. 101 wynika, że wspomniane wotum nieufności może być przyjęte jedynie wtedy, jeżeli opowiada się za tym absolutna większość głosujących w jednej z izb Kongresu Narodowego.

W konsekwencji argentyński Szef Gabinetu Ministrów ponosi podwójną odpowiedzialność polityczną, gdyż odpowiada jednocześnie przed prezydentem ${ }^{52}$. Gdy prezydent Republiki negatywnie ocenia działalność tego urzędnika federalnego, może w każdej chwili podjąć decyzję o odwołaniu go z zajmowanego stanowiska.

\section{BIBLIOGRAFIA}

Badeni G., Reforma constitucional de 1994, „Pensar en Derecho” 2014, nr 5.

Badeni G., Tratado de derecho constitucional, T. 1-2, Buenos Aires 2006.

Barrazy J. I., Schafrik F. H., El Jefe de Gabinete de Ministros, Buenos Aires 1999.

Bożyk S., Konstytucyjny status parlamentu w państwach Ameryki Łacińskiej (Argentyna, Kolumbia, Meksyk), [w:] M. Grzybowski, G. Kuca, P. Mikuli (red.), Ustroje. Historia i współczesność. Polska - Europa - Ameryka Łacińska, Kraków 2013.

Campos Bidart G. J., Manual de derecho constitucional Argentino, Buenos Aires 1979.

Dalla Via A. R., Manual de derecho constitucional, Buenos Aires 2011.

Ekmekdjian M. A., Tratado de derecho constitucional. Constitución de la Nación Argentina, comentada, y anotada con legislacion, jurisprudencia y doctrina, T. 1-5, Buenos Aires 2004.

Lorenzo C. R., Manual de historia constitucional Argentina, T. 1-3, Rosario 2000.

Menem E., Derecho procesal parlamentario, Buenos Aires 2012.

Molinelli G. N., Palanza V. M., Sin G., Congreso, presidencia y justicia en Argentina, Buenos Aires 1999.

Pérez Corti J. M., Derecho electoral Argentino, Córdoba 2012.

Rosas Lopez J. R., Historia constitucional Argentina, Buenos Aires 2014.

Sola J. V., Manual de derecho constitucional, Buenos Aires 2010.

Zarini H. J., Constitución Argentina. Comentada y concordada, Buenos Aires 2013. 


\section{CONSTITUTIONAL STATUS OF EXECUTIVE POWER IN THE REPUBLIC OF ARGENTINA}

Argentina's Constitution of 1853 introduced a presidential system of government. In this system, executive power is exercised by the president of the Republic of Argentina who is elected by general and direct elections. The president is the head of state and heads the federal administration. An additional organ of executive power since1994, is the head of the Cabinet of Ministers.

Keywords: Republic of Argentina, constitution, system of government, the executive, the President of the Republic, head of the Cabinet of Ministers

Słowa kluczowe: Republika Argentyny, konstytucja, system rządów, władza wykonawcza, Prezydent Republiki, Szef Gabinetu Ministrów 